\title{
FACTORS INFLUENCING PARENTS' CHOICES ABOUT ENROLLING THEIR CHILDREN'S IN PRIVATE SCHOOLS (A CASE STUDY IN JALALABAD CITY)
}

\author{
Qudratullah Nazari \\ Senior Teaching Assistant \\ Pedagogy Department \\ Faculty of Education \\ Kandahar University, Kandahar, Afghanistan \\ E-mail: qudrat_n231@yahoo.com \\ Enayatullah Dadman \\ Joiner Teaching Assistant \\ History Department, Faculty of Education \\ Kandahar University, Kandahar, Afghanistan \\ E-mail: dadmanenayat@gmail.com
}

\begin{abstract}
The sight of this research paper was to examine the key components of impacting parent's choice select privet schools for enrollment of their children's, in Jalalabad city therefore this research paper was designed to find out the most important factors in the mention topic, otherwise for the collecting of data used survey method and the instrument of the data was interview with parents who choose privet schools for their children's education level, the present study find out three most important factors which are security threats, digital education system, and teachers hiring, the result clearly indicate that privet schools are better for their children's according to security sects, education level and teachers quality that are hire by education services providers, the findings also show that parents got great feedback from privet school services and they were satisfied from school administrations and schools staff, it is sagest for further researches that many more of factors will consider in this section.
\end{abstract}

Keywords: Digital Education, Factors, Influencing, Teachers Hiring, Security Threats.

\section{INTRODUCTION}

Enrolment trend in government schools is declining continuously year wise. And parents are preferring private schools for the education of their children's. Guardians are the essential caregivers who are mindful and hold a noteworthy part in their children's prosperity (Hamid et al., 2019). Variables impacting parents' choice on preschool arrangement related to parents' inclinations, fulfillment and inclusion in social organize were evoked (Hamid et al., 2019). Quality instruction arrangement is the most figure which draws in guardians to send their children to favored schools (Msendekwa \& Lubuva, 2019). The development of technology, particularly information technology brings a real impact on various aspects of life including children's education (Hidayati, 2020). Education for children is one of the foremost concerning issues within 
the society particularly among the guardians (Kampanatsanyakorn, 2020). Guardians are willing to spend a part of cash each year to contribute in their children's education at the cost of their family budget. There are parcels of components affecting guardians amid the choice making prepare of school selection. Education may be a service advertised by many providers. There's a global development of privatization of education service which has presented a modern challenge for parents and students.

A large body of this research paper is conducted to investigate the parent's choices for enrollment of their children's in private schools, in addition there are lots of private schools in Jalalabad city, they provide may more educational services, but these educational services are in competitive based, within these Private school providers try to get parents' attention. Normally they worked under the supervision of ministry of education in Afghanistan. Each year, many of private schools in Afghanistan open their entryways for parents and children who are viewed as client, in Jalalabad city there's no question that parents choose what is best, within their financial implies, for their children. Parents send their children to private schools to have better education with better educational ethics.

This research paper will consider parent's choices for enrollment of their children's in private schools within this research paper will be find out the key elements Influencing Parents' Choices about enrolling their children's in Private Schools.

\section{REVIEW OF LITERATURE}

Based on elements Influencing Parents' Choices Choosing Private Schools research in Malaysia there are many factors for parents to enroll their children's in privet schools, finding of this research shown that parents emphasizing on the importance of privet schools, the academic performance of privet schools, quality of teachers and environment of the schools (Yaacob et al., 2014). An assessment of factors influencing parents' decision making when choosing a private school for their children a case study of Selangor, Malaysia, finding of this research shown that parents income level is big potential for choosing privet schools (Yaacob et al., 2014). Factors influencing parents' decision in selecting private schools in Chittagong city, Bangladesh, the purpose of this research is to examine the factors influencing the parents' decision in selecting private schools in Chittagong city, Bangladesh. Factors finding in this research are schools popularity, school quality, future option, parents' income level and parents' educational level (Suppramaniam et al., 2019). Factors Influencing Parents' Selection of Schools for Children with Disabilities, according to findings of this research the factors when choosing schools, including the availability of special education programs, distance of the school, social continuities, class size, teachers' characteristics, parent-teacher communication, beliefs about disability, and the children's well-being. Socioeconomic status and parents' areas of residence had a mixed influence on the decision-making process (Mawene \& Bal, 2018). Elements Impacting Parents' Choices on choosing an Islamic Essential School in Bandung Indonesia, finding of this research includes that $86.67 \%$ of parents tend to choose Islamic-based school. Within this, the schools must also be supported by professional educators, produce religious and outstanding graduates, provide not only good environment and quality, but also adequate information technology, along with complete facilities and effective learning time, with these conditions it must that the graduates will be excellent in ethics, morality and religiosity (Hidayati, 2020). Due to findings of a study on the factors influencing parent's decision in choosing private schools in Selangor, it was found that parents expected school's syllabus, school's environment, school performances, teacher's quality, location, distance, social background and income level are main points for their children's to enroll 
in privet schools (Yaacob et al., 2015). Perceived school characteristics, quality of education physical environment and extracurricular activities are the key points and findings of a research, why do Parents Choose to Send Their Children to Private Schools? (Davis, 2011). Parents and guardians send their children to Pre-primary schools due to different reasons. Some send children to a certain school because of social, physical and psychological issues. Some parents send their children to preprimary believing that they build good foundation for the child's academic future (Adzima, 2014). Factors parents consider in selecting pre-primary schools for their children, findings revealed that parents consider four major factors namely academic quality, affordability of school fees, language of instruction and class size in school selection (Msendekwa \& Lubuva, 2019). Certain demographic are more accepting to some attribute and limitation than others. Factors that influence Thai parents in choosing preschool program. Guardians have a noteworthy impact on their children's improvement and future accomplishment. It is critical for guardians to create the proper choice with respect to their children's instruction particularly preschool since amid this age child create more quickly and learn faster than at any other time in their life (UNICEF, 2010). program, area, school expenses, teachers' qualities and school environment impact on the parents' choice and gave great criticism and were fulfilled with the preschool organization are most important in a research on factors element affecting Parents' Choice of Preschool Instruction in Malaysia (Taha, 2019). Perceived behavioral control is the main influence factor for Chinese parents' to enroll their children's in primary schools Sarawak, Malaysia (Lee et al., 2017). Parents preferred single-sex education. Also preferred schools with qualified teachers, excellent academic record, and adequate support services are parents' choice of a particular senior high school in Ghana (Amonoo, 2014). Factors Affecting Parents' Inclination towards Private School System in Pakistan based on this research Parents think that quality of education in private schools is better than government schools, provide safe environment in school to children, children are safer in private school due to proper security, private schools provide quality environment to students in school premises that ultimately impacts the quality education of learners, teaching procedures, assessment of students, and teacher learner interaction is better handled in private schools, teachers in private school work with dedication and teachers take job stress keeping in mind the reality that their job cannot continue unless showing good performance to employer (Akhter, 2017).

\section{METHOD}

The scope of this research paper is to have farther understanding about parents' decisions for choosing private school learning establish on Afghan heritage learning system in Jalalabad city, then revising sampling techniques used random survey method for collecting true data, it was establish on research decision which accepted that the chosen overview have the capacity to prepare the desired information, in expansion a collection of collected overviews incorporate guardians who chosen private schools for enrollment of their children's in Jalalabad city, this method is more suitable for collecting wide range of true data and discussion was the information collection instrument and the information was analyze theoretically.

\section{RESULTS}

Parents decisions choosing private schools for enrolling their children's will have based on challenging limitation in education system furthermore security threats are the key factors that parents make decision choose private schools, anyway there are more factors influencing parents make decision for their children's education. 


\section{Security Threats}

One of the most important factor that parents make decision to enroll their children's in private schools was security threats, parents emphasized that Our country Afghanistan is a war-torn country and the public education system is in a more serious crisis at the current time within this security threats are challenging at the educational level, Private schools in Jalalabad are equipped with transportation system and parents don't need pickup their children's every morning and evening. The finding of this factor is presented as in figure 1.

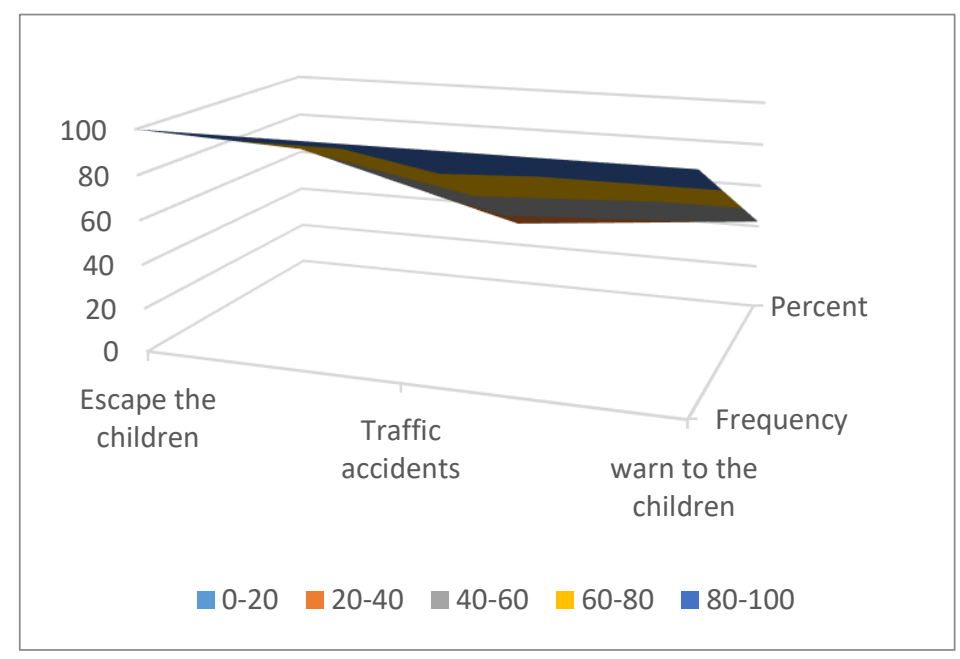

Figure 1. Show the range of security threats factor.

Figure 1. Show that the main security threats are escape the children's, traffic accident and warn to the children's in these factors $61.5 \%$ are escaping events, $31 \%$ are traffic accident events and 42.3 are the warn events. According to these conditions parents make decision to enroll their children's in private schools.

\section{Digital Education System}

According to parent's views most of privet schools in Jalalabad city provide digital education system it means the school classes are equipped on security cameras, teaching and learning process are by projectors, digital library, internet access, computer labs, conference halls and digital attendance. These factor are presented on figure 2 .

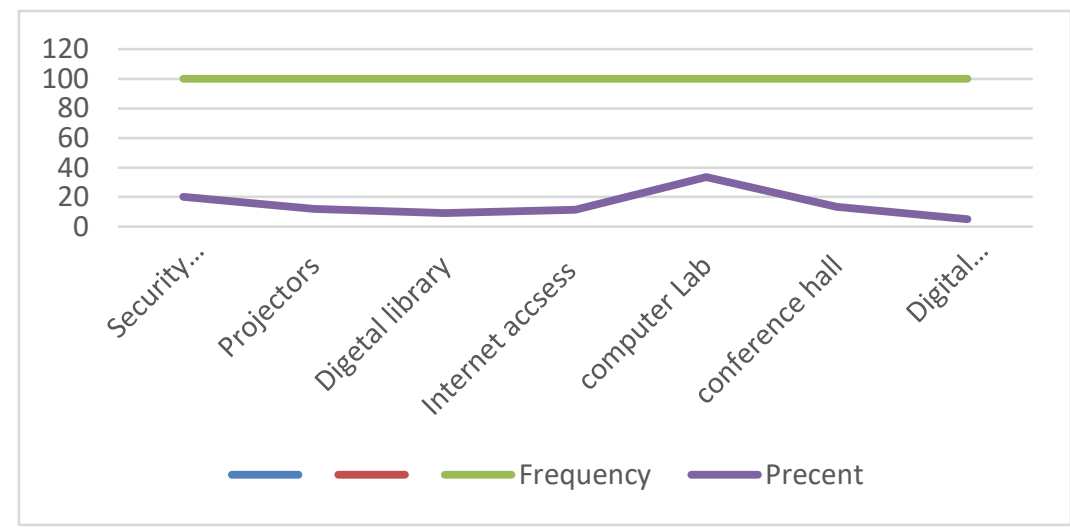

Figure 2. Shown the range of digital education system factors 
Based on view of figure 2, factors that parents make decision to enroll their children's in private schools are security camera, projectors, digital library, internet accesses, computer lab, conference hall and digital attendance.

\section{Professional Teachers}

Another factor that parents influence to send their children's to private schools was the hiring of professional teachers, according to parents emphasizes many of them are most agree that private schools in Jalalabad city have professional teachers. Parent's satisfactions are presented in chat 3.

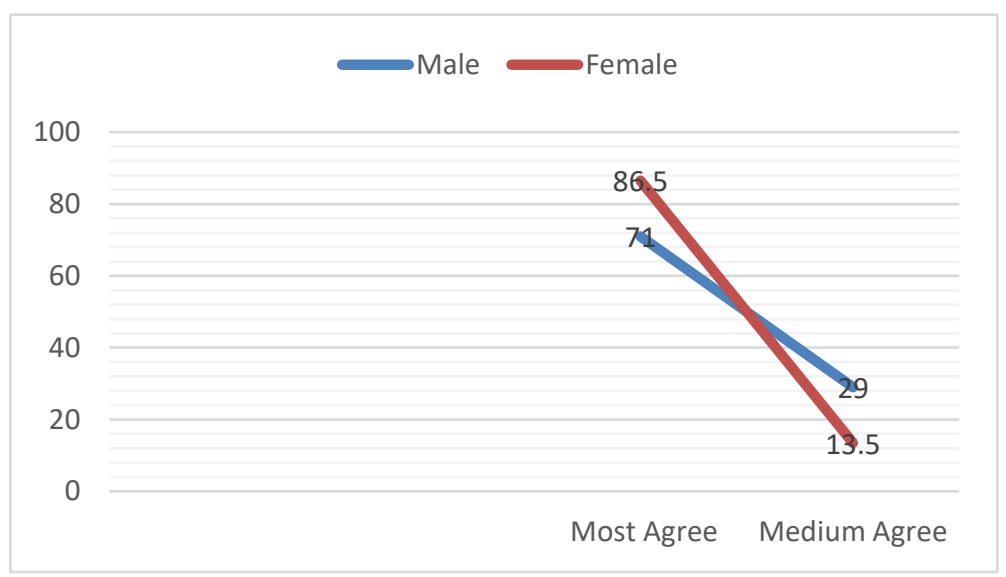

Figure 3. Shown the satisfactions of parents with hiring of professional teachers in privet schools.

\section{DISCUSSION}

A large body of this research paper examine factors influencing parents' decision choosing. Private Schools for enrollment of their children's, Parents in this study believed that factors influence them and make decision to choose privet schools are security threats, digital education system and hiring professional teachers these the are main factors for engaging their children's education level, according to literature review of this research paper findings of most research are academic performance, school environment, schools fee level, teaching procedure, students assessment, schools facilities and schools future academic programs. Otherwise the most important things that parents were agree with that was the children's security.

\section{REFERENCES}

Akhter, N. (2017). Factors Affecting Parents' Inclination towards Private School System in Pakistan. Journal of Elementary Education, 27(2), 49-69.

Adzima, K. (2014). The factors influencing parental valuation of Pennsylvania charter schools in grades 3-6. Journal of School Choice, 8(2), 159-191.

Amonoo, J. (2014). Factors influencing parents' choice of a senior high school for their children (Doctoral dissertation, university of cape coast).

Davis, A. M. (2011). Why Do Parents Choose to Send Their Children to Private Schools: Georgia Southern University, Georgia, Electronic Theses and Dissertations? 382, Retrieved from https://digitalcommons.georgiasouthern.edu/etd/382 
Hidayati, D., \& Rifa'i, A. A. (2020). Factors Influencing Parents' Decisions on Choosing an Islamic Primary School in Bandung Indonesia. Randwick International of Social Science Journal, 1(1), 121-126.

Hamid, O., Robert, C., Daud, A., Hodi, F. S., Hwu, W. J., Kefford, R., ... \& Ribas, A. (2019). Five-year survival outcomes for patients with advanced melanoma treated with pembrolizumab in KEYNOTE-001. Annals of Oncology, 30(4), 582-588.

Kampanatsanyakorn, O. (2020). Factors influencing parents' choice in pre- schools' selections in Thailand: Mahidol University, Thailand.

Lee, D. P. Y, Ting, S. H. \& Lo, M. C. (2017). Chinese or Malay-medium schools? A study of factors influencing Chinese parents' choice of primary schools in Sarawak, Malaysia. Kajian Malaysia, 35(1), 41-67. https://doi.org/10.21315/km2017.35.1.3.

Mawene, D., \& Bal, A. (2018). Factors Influencing Parents' Selection of Schools for Children with Disabilities: A Systematic Review of the Literature. International Journal of Special Education, 33(2), 313-329.

Msendekwa, M. B, \& Lubuva, A. H. (2019). Factors influencing parent's decisions to choose preschools for their Childers: Journal of Co-operative and Business Studies (JCBS), 4(1).

Suppramaniam, S. I., Kularajasingam, J. A., \& Sharmin, N. H. (2019). Factors Influencing Parents Decision in Selecting Private Schools in Chittagong City, Bangladesh: International Journal of Recent Technology and Engineering, 7(5).

Taha, N, M, Talib, J, I, Salleh, M, A, \& Farhah, T, S. (2019). A Study on Factors Influencing Parents' Choice of Preschool Education in Malaysia: International Journal of Innovation, Creativity and Change, 6(1).

UNICEF. (2010). Progress for children: achieving the MDGs with equity (No. 9). Unicef.

Yaacob, N. A., Osman, M. M., \& Bachok, S. (2014). Factors influencing parents' decision in choosing private schools. Procedia-Social and Behavioral Sciences, 153, 242-253.

Yaacob, N. A., Osman, M. M., \& Bachok, S. (2015). An assessment of factors influencing parents' decision making when choosing a private school for their children: a case study of Selangor, Malaysia: for sustainable human capital. Procedia environmental sciences, 28, 406-417.

\section{Copyrights}

Copyright for this article is retained by the author(s), with first publication rights granted to the journal. This is an open-access article distributed under the terms and conditions of the Creative Commons Attribution license (http://creativecommons.org/licenses/by/4.0) 